\title{
Development of Learning Media Based on Videoscribe to Improve Learning Outcomes of Morphology Course
}

\author{
Mulyono Mulyono ${ }^{1, *}$ Arie Yuanita ${ }^{1}$ Dianita Indrawati ${ }^{2}$
}

\author{
1, 2 Universitas Negeri Surabaya, Indonesia \\ *Corresponding author.Email: mulyono@unesa.ac.id
}

\begin{abstract}
Learning media is an integral part of the lecture (learning) process. If it is inappropriate and ineffective, it will disturb other learning components, and lecture competencies will be hampered. The learning media developed in this research is Videoscribe in the Morphology course. The goals is to describe the development process and the quality of Videoscribe learning mediato improve learning outcomes of Morphology lectures. The method used a Recursive, Reflective, Design, and Development (R2D2) design model with several stages, namely the analysis stage, the design stage, the development stage, and the evaluation. The validator validates the resulting learning media by filling out an assessment questionnaire to determine the feasibility of the video that has been developed. The results of the assessments from material experts and media experts produced learning media with the criteria of "fit for use without revision". Products that experts have validated are then tested on students, accompanied by filling out a response questionnaire to determine the feasibility and attractiveness of the Videoscribe that has been developed. The results meet good qualifications with the criteria of "agree." In conclusion, the development of the Videoscribe learning media in the Morphology Course is feasible and enjoyable to use for students.
\end{abstract}

Keywords: Development, Learning Media, Videoscribe, Morphology.

\section{INTRODUCTION}

The Morphology course is one of the compulsory subjects for students of the Indonesian Literature Study Program. This course examines the structure of Indonesian words, the basic concepts of morphology (morphs, morphemes, allomorphs, morphophonemic, morpheme forms, morphological processes, morphological analysis), new symptoms of Indonesian word formation, and the functional relationship between the substance of linguistics and Indonesian literature through classroom and online meetings, and field research to produce linguistic analysis/study products and language research products to be presented in class discussions and used as an alternative source of reference for further research. This shows the central role of the Morphology course in language learning, especially for students of the Indonesian Literature Study Program. Learning is a complex process in students and its success involves many components in it. With a fairly high and abstract achievement target as described above, Morphology lectures must be packaged in an attractive manner so that it can stimulate students' learning enthusiasm. Students' understanding of the lecture material is also determined by the relevance and shrewdness of the lecturer in choosing and applying a learning media [1].

Learning media is an integral part in the lecture process. The influence of learning media on other learning components is quite large. In other words, if the learning media used is not appropriate and effective, then the other learning components will also be disrupted and the achievement of lecture competencies will be hampered [2]. By paying attention to the importance of learning media for the achievement of lecture competencies, the stages of development need to be observed so that the production process runs smoothly and the resulting learning media can be applied effectively [3]. The stages of developing Videoscribe learning media. This begins with needs analysis, preparation of media content outlines (PMCO) and material descriptions (MD), media script writing, prototype production, prototype testing, and reviewing the results of prototype development [4].

Technology is a vehicle that has the potential to help toward effectively meeting learning and assessment needs [5]. One of the learning media combined with 
technology is Videoscribe. It is a learning media with audio-visual characteristics that are applicable to information and communication technology devices [6]. This type of audio-visual media can seize $94 \%$ of the message/information channel that enters the human psyche through the eyes and ears and is able to make people in general remember $50 \%$ of what they see and hear on program shows. Messages conveyed through video media can affect strong emotions and can also achieve fast results that other media do not have [7].

In this study, the learning media that will be developed for Morphology lectures is Videoscribe learning media. The development of this learning media will utilize teaching materials used in classroom and online meetings in morphology course. The Videoscribe learning media development is expected to be able to increase the achievement of student competencies [8].

\section{METHODS}

In general, this study aims to develop Videoscribe learning media to improve the final results of learning Morphology. This research is categorized as a Research and Development study [9]. The development model used in this study is the Recursive, Reflective, Design, and Development (R2D2) design model. Willis and Wright in Mulyono stated that the R2D2 procedure has the characteristics of (1) a determination focus, (2) a design and development focus, and (3) a dissemination focus that is modified according to the context of the development environment and needs [10]. These three focuses are activities carried out during the research and development process. In practice, each of these activities does not always run linearly, but also circularly. The determination focus takes place at the analysis stage, the design focus occurs at the planning stage, and the development focus takes place at the development stage [11]. The focus of dissemination is in the form of a focus on disseminating the results of product development that has been made.

The stages of the research can be described in the form of a flow chart of research activities as follows.

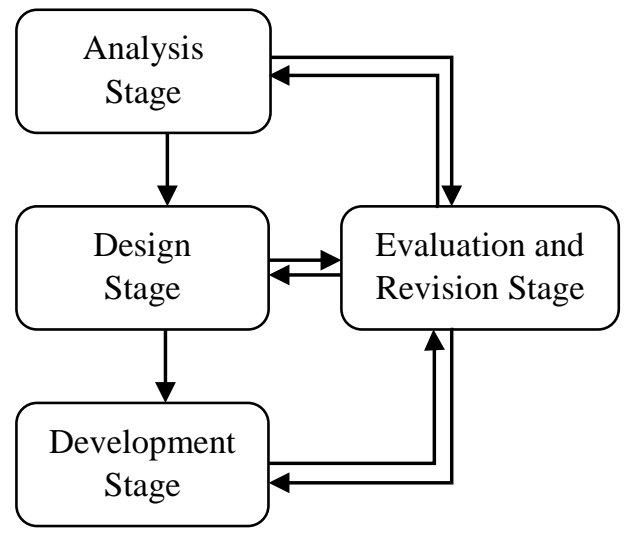

Figure 1 The stages of the study

\subsection{Analysis stage}

At this stage a preliminary study is carried out with the aim of digging up the information needed in the development of the learning media that will be made. Information is obtained through needs analysis and related document review and literature review. At the stage of analyzing student needs, researchers collect data and information related to problems/characters and student needs which include: a) curriculum content analysis, b) student initial ability analysis, c) analysis of the availability of learning resources, d) analysis of learning tasks, e) analysis of learning models and methods, and f) analysis of the use of learning media.

\subsection{Design Stage}

The design stage of the development of this learning media is determined by using an application Videoscribe. At this stage, researchers identify competencies that need to be mastered by students, formulate learning objectives that must be achieved, determine the content of the material as learning materials, create media storyboards to be developed, and design all required instruments.

\subsection{Development Stage}

At this stage, the media is produced according to the design that has been made. The Videoscribe media includes an opening section consisting of the title of the material based on an attractive display/image accompanied by appropriate music, a material content section in the form of a description and explanation of the material presented in the learning media, and a video closing section containing a thank you to students. /media user Videoscribe.

\subsection{Evaluation and Revision Stage}

At this stage, researchers do two activities, namely expert assessment and testing product. Expert validation involves two experts who will review the resulting product, namely material experts and media experts who are competent in their fields. There are three types of questionnaires developed, namely material validation questionnaires, media validation questionnaires, and student response questionnaires. After revisions were made based on the results of expert reviews and student responses, the final product was developed in the form of Videoscribe media for the Morphology course which was considered ideal.

\section{RESULTS AND DISCUSSION}

The results of research and development that have been carried out are in the form of Videoscribe learning media with Morphology teaching materials. As 
mentioned earlier that development research with the R2D2 design model focuses on (1) determination, (2) design and development, and (3) dissemination which is modified according to the context of the development environment and needs. The procedure is carried out from the beginning to the end, namely the analysis stage (focusing on determination), the planning and media development stage (focusing on design and development), and the stage of disseminating the results of product development that have been prepared to determine the qualifications of product results (focusing on dissemination) [12].

\subsection{Analysis stage}

In this study, the initial stage carried out was an analysis of the needs of the media to be developed and an analysis of the character of students who would use the media. The results of the analysis are used as a reference in the development of learning videos.

\subsubsection{Needs analysis}

The existence of learning media is needed to deal with problems that occur in the learning process in schools and universities. Like what happened at the State University of Surabaya, lectures still really need the presence of learning media that can encourage students to learn and increase student independence in learning. Therefore, the development of learning media is oriented to the application of the results of modern technological advances so that it can produce interesting learning media and can motivate students to improve their learning outcomes.

\subsubsection{Analysis of student characteristics}

Researchers as lecturers of the Morphology course can find out that there are still many students who have difficulties when attending lectures. Morphological concepts that are somewhat abstract often fail to be well understood. Lecture materials in the form of explanations are also still less attractive to students.

As a result, the level of student understanding of the lecture material has not been satisfactory. In accordance with the results of the needs analysis and analysis of student characteristics above, the researchers tried to develop learning media for Morphology course material. This learning media aims to facilitate the delivery of lecture material which is still considered abstract by students and to increase student independence in learning. This learning media is made with the help of Videoscribe applications that is applicable to information and communication technology so that it can be made with a combination of attractive appearance and easy to use and easy to viral via the internet network.

\subsection{Design Stage}

After conducting the analysis stage, the next step is the design stage. The design stage of the development of learning media is carried out using a Videoscribe application.

\subsubsection{Analyzing goals}

The analysis of the objectives for the development of this media is based on the learning objectives that have been set in the semester lecture plan (SLP/RPS), including:

(1) Students are able to explain the meaning of affixes, explain the meaning of the process of affixing affixes, explain phoneme changes due to the affixing process (morphophonemic process), and identify phoneme changes due to the process of affixing affixes.

(2) Students are able to explain the meaning of the compounding process, identify the characteristics of words that undergo a compounding process and identify the types of compounding in Indonesian.

(3) Students are able to explain the function of affixed morpheme, explain the function of repeat morpheme, and explain the function of compound morpheme.

(4) Students are able to explain various acronymization processes, identify words formed through the acronymization process, use various words formed through the acronymization process in several sentences correctly.

\subsubsection{Material preparation}

The material chosen by the researcher for the development of this learning media is Affixation, Composition, Morpheme Function, and Acronymization in the Morphology course. Affixation and Acronymization material was chosen because the material would be more interesting if it was delivered in the form of a videoscribe while the composition and function of morpheme material was chosen because it was considered a bit abstract and quite difficult to understand if studied only from printed books. Based on the selected lecture material, then a description of the media development material (DMDM) is made as a guide in making media.

\subsubsection{Storyboarding}

Making a storyboard starts from the making of the initial scenario of the opening of the video, the introductory scenario of the material, the explanation of the material, and the delivery of the closing. The initial opening video is in the form of a learning material title that is designed to be attractive and accompanied by 
appropriate music. In the explanation section of the material, interesting animations and pictures are given according to the material accompanied by background music and the voice of the narrator who explains the material. The closing section contains a thank you to the video users.

\subsubsection{Instrument design}

The instrument used for the dissemination of learning media products in this study was a questionnaire. As an instrument, the questionnaire is prepared based on aspects that are adapted to the objectives of each questionnaire. These instruments include an evaluation questionnaire filled out by material experts and media experts. The instrument for media assessment is in the form of a questionnaire (checklist) filled out by validators and students. The questionnaire filled out by the validator is used to assess the quality of the product, while the student questionnaire is to determine student responses to the use of Videoscribe learning media which was tested.

\subsection{Development Stage}

At the development stage, the media is produced according to the designs that have been made in the design stage.

\subsubsection{Opening Video}

The opening video consists of the title of the material. The background of the video is made with an attractive display/image accompanied by appropriate musical accompaniment. The opening video is made as attractive as possible to attract the attention and interest of students. The following is an example of an opening video display that has been designed and produced by researchers.

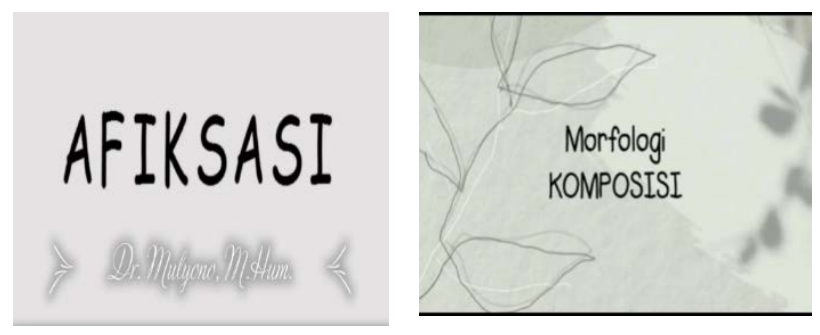

Figure 2 Examples of an opening video display

\subsubsection{Contents}

The contents of the material are in the form of descriptions and explanations of the material presented in the learning media. The following is an example of the appearance of Morphology course material in learning media that has been developed into Videoscribe.
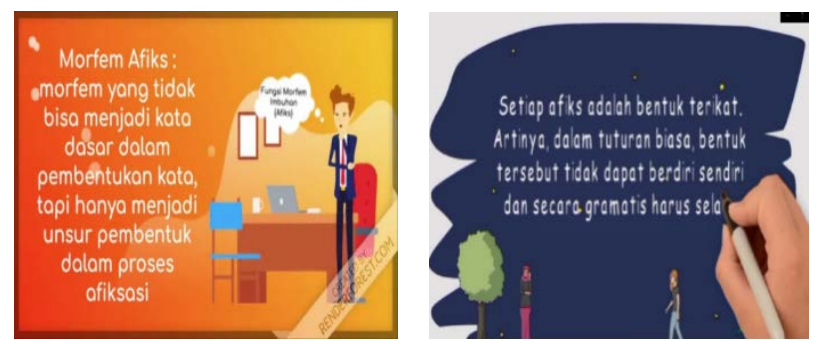

Figure 3 Examples of the appearance of Morphology course material

\subsubsection{Video Closer}

The closing part of the video contains a thank you to students/users of learning media. The following is an example of the display of the closing section of the Morphology course learning media which has been developed into a Videoscribe.
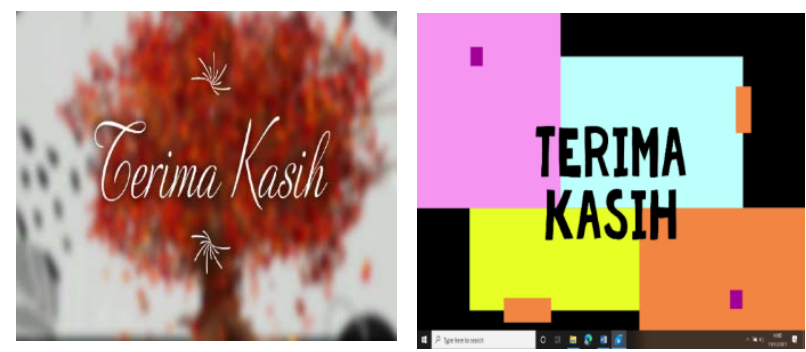

Figure 4 Examples of the display of the closing section of the Morphology course learning media

\subsection{Evaluation and Revision Stage}

\subsubsection{Product Validation}

In this study, researchers used a product validation questionnaire instrument that was used to measure the quality of the learning media that had been produced. There are two types of questionnaires developed, namely material validation questionnaires and media validation questionnaires.

\section{(1) Validation Results from Material Expert}

Material expert validation is carried out in testing the completeness of the material used in the test 1 videoscribe with aspects such as the suitability of the material, the accuracy of the material, encouraging student curiosity, presentation techniques, coherence and coherence in the flow of thought, as well as contextual. The validation values by material experts are as follows. 
Table 1. Validation results from material expert

\begin{tabular}{|c|l|c|c|c|c|c|}
\hline \multirow{2}{*}{$\begin{array}{c}\text { No } \\
\cdot\end{array}$} & \multicolumn{1}{|c|}{ Aspect } & \multicolumn{5}{c|}{ Category } \\
\hline & & $\mathbf{1}$ & $\mathbf{2}$ & $\mathbf{3}$ & $\mathbf{4}$ & $\mathbf{5}$ \\
\hline 1 & Material Suitability & & & & & $\sqrt{ }$ \\
\hline 2 & Material Accuracy & & & & & $\sqrt{ }$ \\
\hline 3 & Encourage Curiosity & & & & $\sqrt{ }$ & \\
\hline 4 & Presentation Technique & & & & & $\sqrt{ }$ \\
\hline 5 & $\begin{array}{l}\text { Coherence and } \\
\text { Coherence of Thoughts }\end{array}$ & & & & $\sqrt{ }$ & \\
\hline 6 & Contextual & & & & & $\sqrt{ }$ \\
\hline
\end{tabular}

(2) Validation Results from Media Expert

Media expert validation was carried out to test the feasibility of Videoscribe being used as a learning medium with aspects such as coloring, use of words and language, display and screen, presentation, animation, and sound. The validation values by media expert validator are as follows.

Table 2. Validation Results from Media Expert

\begin{tabular}{|l|l|c|c|c|c|c|}
\hline \multirow{2}{*}{ No } & \multicolumn{2}{|c|}{ Aspect } & \multicolumn{5}{|c|}{ Category } \\
\hline & & $\mathbf{1}$ & $\mathbf{2}$ & $\mathbf{3}$ & $\mathbf{4}$ & $\mathbf{5}$ \\
\hline 1 & Coloring & & & & & $\sqrt{ }$ \\
\hline 2 & $\begin{array}{l}\text { Use of Words and } \\
\text { Language }\end{array}$ & & & & & $\sqrt{ }$ \\
\hline 3 & Display and Screen & & & & $\sqrt{ }$ & \\
\hline 4 & To serve & & & & & $\sqrt{ }$ \\
\hline 5 & Animations and Sounds & & & & $\sqrt{ }$ & \\
\hline
\end{tabular}

Based on the results of the questionnaire assessment above, it is known that the average value of the assessment of teaching materials that have been developed by researchers is as follows.

(a) Material aspect value

$\underline{28} \times 100 \%=93 \%$

30

(b) Media aspect value

$\underline{23} \times 100 \%=92 \%$

25

While the qualitative suggestions from the two experts were (1) The content of the video material was good enough, (2) the learning video was good enough.

The two experts by paying attention to the score on each aspect of the assessment on the validation sheet, the check mark $(\sqrt{ })$ selected to indicate the conclusion is as follows:

$(\sqrt{ })$ suitable for use without revision because the material is complete, broad, and in accordance with the RPS (> 90\%);

$(\sqrt{ })$ suitable for use without revision because the media is complete, clear and attractive according to RPS (> 90\%);

\subsubsection{Product Trial}

After the product was assessed by the validator, the product was tested on students of the Indonesian Literature Study Program, State University of Surabaya Class of 2020 with a large class trial of 35 students. This trial aims to find out the attractiveness and convenience of the learning videos that have been made. In the last stage, students are given a questionnaire using the Google form menu for assessment of assisted learning media Videoscribe. The results of student trials can be seen in the following recapitulation table (Table 3). 
Table 3. Recapitulation of student questionnaire results for Videoscribe learning media users in morphology course

\begin{tabular}{|c|c|c|c|c|c|}
\hline \multirow[b]{2}{*}{ No } & \multirow[b]{2}{*}{ Question } & \multicolumn{4}{|c|}{ Category } \\
\hline & & Disagree & $\begin{array}{l}\text { Somewhat } \\
\text { less Agree }\end{array}$ & Agree & $\begin{array}{l}\text { Strongly } \\
\text { Agree }\end{array}$ \\
\hline 1 & $\begin{array}{l}\text { Can the use of Videoscribe learning media in } \\
\text { Morphology lectures encourage your curiosity? }\end{array}$ & & & 29 & 6 \\
\hline 2 & $\begin{array}{l}\text { Is the appearance of the Videoscribe learning } \\
\text { media in Morphology lectures interesting } \\
\text { enough? }\end{array}$ & & & 31 & 4 \\
\hline 3 & $\begin{array}{l}\text { Does the Videoscribe learning media in } \\
\text { Morphology lectures use understandable words } \\
\text { and language? }\end{array}$ & & & 30 & 5 \\
\hline 4 & $\begin{array}{l}\text { Is the material on the Videoscribe learning } \\
\text { media in Morphology lectures easy to } \\
\text { understand? }\end{array}$ & & & 32 & 3 \\
\hline 5 & $\begin{array}{l}\text { Did the use of the Videoscribe learning media in } \\
\text { Morphology lectures interest you? }\end{array}$ & & & 30 & 5 \\
\hline
\end{tabular}

From the recapitulation table of Videoscribe media user student questionnaires in the Morphology course, the majority of students answered "agree". This shows that the learning videos that have been developed by researchers have been approved by users, namely students, to be able and suitable to be used as learning media in Morphology lectures for students of the Indonesian Literature Study Program, State University of Surabaya.

\section{CONCLUSION}

Development research of learning media based on Videoscribe to improve learning outcomes of this Morphology course using a Recursive, Reflective, Design, and Development (R2D2) design model with the stages of analysis, planning, development, and evaluation. Through the analysis, planning, and development stages, four Videoscribe learning media were produced with Affixation, Composition, Morpheme Function, and Acronymization materials. The four learning media that have been produced are then validated by the validator by filling out an assessment questionnaire to determine the feasibility of the video that has been developed. The results of the assessment from material experts and media experts concluded that the learning media that had been produced were qualified to be "suitable for use without revision". Learning media that have been validated by experts are then tested on students accompanied by filling out a response questionnaire to determine the feasibility and attractiveness of the applied video and the results are qualified "agree". Thus, it can be concluded that the Videoscribe-based learning media that has been developed for the Morphology course is feasible and interesting to use and contribute to improving student learning outcomes.

\section{REFERENCES}

[1] A. Arsyad, Media Pembelajaran: Pedoman penulisan modul. Jakarta: Rajawali pers Depdiknas, 2011.

[2] C. Manning, W. Brooks, V. Crotteau, A. Diedrich, J. Moser, and A. Zwiefelhofer, "Tech tools for teachers, by teachers: bridging teachers and students," Wisconsin English J., vol. 53, no. 1, pp. 24-28, 2011.

[3] Y. Munadi, "Media Pembelajaran; Sebuah Pendekatan Baru (Cetakan ke-3).” Jakarta: Gaung Persada (GP) Press, 2010.

[4] E. D. Pratiwi, S. Latifah, and M. Mustari, "Pengembangan Media Pembelajaran Fisika Menggunakan Sparkol Videoscribe,” Indones. J. Sci. Math. Educ., vol. 2, no. 3, pp. 303-309, 2019.

[5] J. Laborda, D. Sampson, R. Hambleton, and E. Guzman, "Guest editorial: Technology supported assessment in formal and informal learning,” Educ. 
Technol. Soc., vol. 18, no. 2, pp. 1-2, 2015.

[6] M. Yusup, Q. Aini, and K. D. Pertiwi, "Media audio visual menggunakan videoscribe sebagai penyajian informasi pembelajaran pada kelas sistem operasi,” Technomedia J., vol. 1, no. 1 Agustus, pp. 126-138, 2016.

[7] S. Arief, "Media pendidikan, pengertian, pengembangan, dan pemanfaatannya," Jakarta PT. Rajagrafindo Persada, 2009.

[8] B. Susanti, "Penggunaan Medua Pembelajaran Video Scribe untuk Meningkatkan Motivasi Belajar Siswa Kelas V Madrasah Ibtidaiyah At-Taqwa Pinang," Nat. J. Kaji. Penelit. Pendidik. dan Pembelajaran, vol. 3, no. 2, pp. 387-396, 2019, doi: https://doi.org/10.35568/naturalistic.v3i2.399.

[9] D. Sugiyono, "Metode penelitian pendidikan pendekatan kuantitatif, kualitatif dan R\&D,” 2013.

[10] Mulyono, Mukhzamilah, and D. W. Rohaedi, "Developing Problem-Based Blended Learning Model for Syntax Course in Industrial Era 4.0,” pp. 214-217, 2019, doi: https://doi.org/10.2991/soshec19.2019.47 (2019).

[11] N. Aryuntini, I. Astuti, and Y. Yuliana, "Development of Learning Media Based on VideoScribe to Improve Writing Skill for Descriptive Text of English Language Study," J. Educ. Teach. Learn., vol. 3, no. 2, pp. 187-194, 2018, doi: https://doi.org/10.26737/jetl.v3i2.74 (2018).
[12]A. N. Aini, "Pengembangan Media Pembelajaran Sparkol Videoscribe pada Materi Transportasi (Program Linear) untuk Mahasiswa Matematika UIN Raden Intan Lampung.” UIN Raden Intan Lampung, 2018. 